\title{
КОНЦЕПЦІЯ СТВОРЕННЯ АЕРОЗОЛЬНИХ ЛІКАРСЬКИХ ФОРМ ДЛЯ ЛІКУВАННЯ ЗАХВОРЮВАНЬ ДИХАЛЬНИХ ШЛЯХІВ
}

\author{
Фітьо І. В., Стадницька Н. Є.
}

\section{ВСТУП}

Створення нових лікарських засобів для лікування захворювань органів дихання $\epsilon$ актуальною проблемою сучасної фармації. Лікування таких захворювань вимагає комплексного підходу, саме тому здебільшого і використовуються лікарські засоби, які безпосередньо впливають на причину хвороби в комбінації з препаратами, які полегшують перебіг захворювання.

Одним із основних симптомів інфекційних захворювань, таких як грип, гострі інфекції дихальних шляхів, застуда, бронхіт і фарингіт $\epsilon$ біль у горлі та кашель. Це перші ознаки, які вимагають якнайшвидшого лікування. Досить часто для лікування цих симптомів використовують синтетичні препарати, проте слід зазначити, що діючі речовини цієї групи лікарських засобів володіють низкою побічних ефектів на організм людини. Саме тому є актуальною розробка лікарських засобів на основі речовин природнього походження, які володіють комплексом певних фармакологічних ефектів. Особливу увагу слід звернути на вибір лікарської форми, яка буде оптимальною для лікування цих симптомів. Вона повинна мати пролонговану дію на слизову оболонку горла та забезпечувати антимікробну та пом'якшувальну дії.

Метою роботи було:

1. проаналізувати ринок лікарських засобів для лікування захворювань органів дихальної системи, які містять фітокомпоненти, стосовно форми їх випуску;

2. на основі результатів аналізу підібрати оптимально ефективну лікарську форму для лікування перших симптомів захворювань дихальних шляхів;

3. запропонувати власну розробку.

Аналіз асортименту препаратів здійснено згідно 3 Державним реєстром лікарських засобів України та класифікаційною системою ATC (Anatomical Therapeutic Chemical classification system). Робота виконана 3 використанням статистичного, логічного і графічного методів. 
1. Найпоширеніші захворювання дихальної системи та аналіз препаратів, які використовуються для їхнього лікування

Для чіткого розподілу захворювань на групи розроблена міжнародна класифікація хворіб (далі - MКХ). Згідно 3 цією класифікацією захворювання системи дихання поділяють на наведені нижче групи (табл. 1).

\section{Таблиця 1}

Розподіл на групи захворювань системи дихання

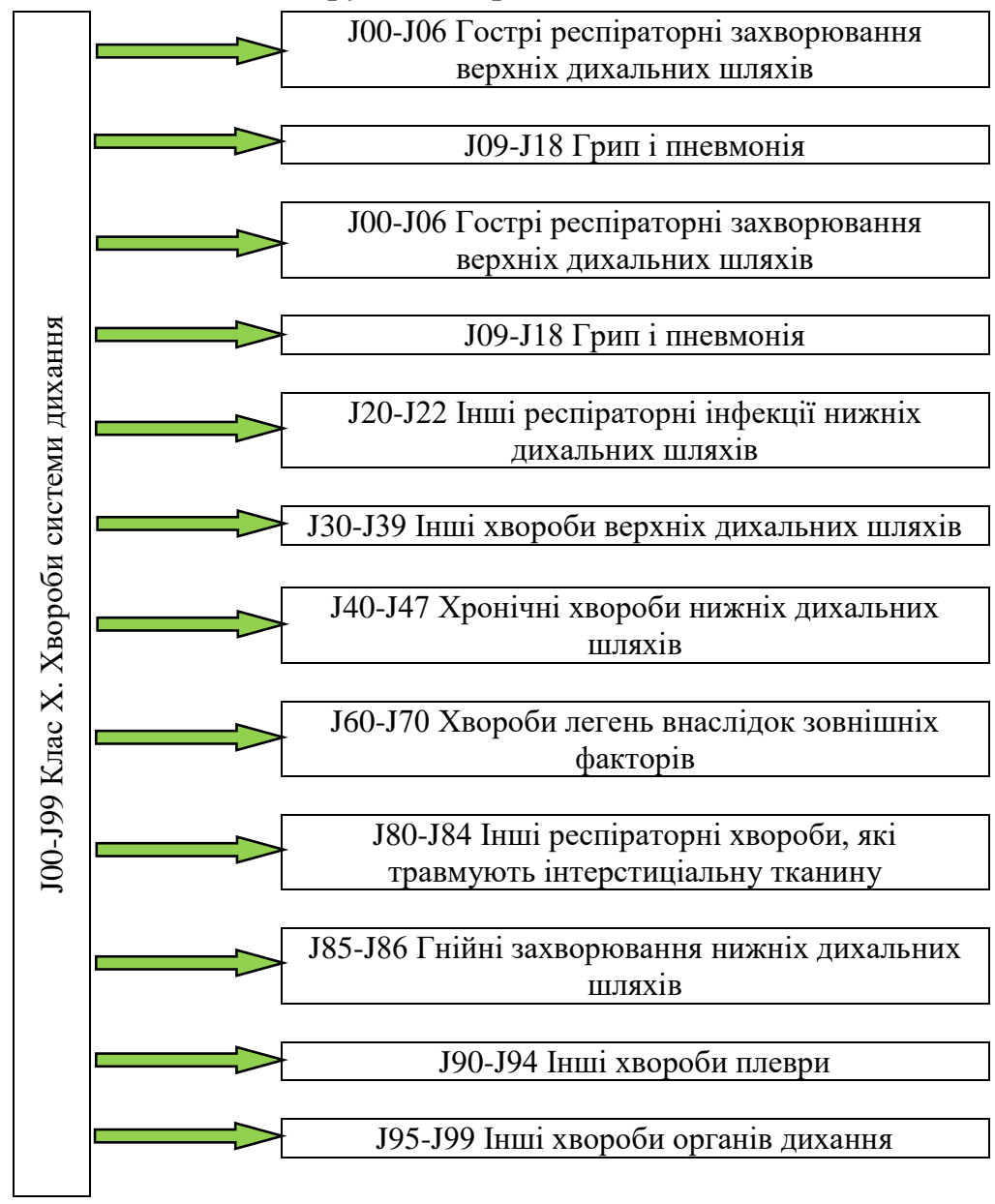


На практиці часто користуються поділом цих захворювань на дві групи:

1) хвороби верхніх дихальних шляхів;

2) хвороби нижніх дихальних шляхів ${ }^{1,2,3}$.

Першу групу складають захворювання J00-J06, а саме гострий назофарингіт (нежить), гострий синусит, гострий фарингіт, гострий тонзиліт, гострий ларингіт і трахеїт, гострий обструктивний ларингіт (круп) та епіглотит, гострі респіраторні інфекції верхніх дихальних шляхів множинної та неуточненої локалізацій. Тобто, це захворювання носової порожнини з приносовими пазухами, носової та ротової частин глотки (табл. 2).

Таблиця 2

Особливості захворювань верхніх дихальних шляхів

\begin{tabular}{|l|l|c|}
\hline \multicolumn{1}{|c|}{ Захворювання } & \multicolumn{1}{|c|}{ Симптоми } & $\begin{array}{c}\text { Група } \\
\text { препаратів для } \\
\text { лікування }\end{array}$ \\
\hline $\begin{array}{l}\text { Гострий } \\
\text { назофарингіт } \\
\text { (нежить) }\end{array}$ & $\begin{array}{l}\text { Закладеність носа, ускладнення } \\
\text { дихання, чхання, набряклість } \\
\text { слизової оболонки та поява } \\
\text { слизисто-гнійних виділень }\end{array}$ & $\mathrm{R} 01$ \\
\hline Гострий синусит & $\begin{array}{l}\text { Закладеність носа, зниження або } \\
\text { зникнення нюху, виділення з } \\
\text { носа (слизові, серозні, гнійні або } \\
\text { змішаного характеру), головний } \\
\text { біль }\end{array}$ & R01 \\
\hline Гострий фарингіт & $\begin{array}{l}\text { Відчуття помірного болю при } \\
\text { ковтанні, рідше - печіння, } \\
\text { гіперемія та набряк слизової } \\
\text { оболонки задньої стінки глотки, } \\
\text { своєрідна зернистість, інколи - } \\
\text { дрібні крововиливи }\end{array}$ & R02 \\
\hline
\end{tabular}

1 Фещенко Ю.І., Яшина Л.О., Дзюблик О.Я. Хронічне обструктивне захворювання легень: етіологія, патогенез, класифікація, діагностика, терапія // Український пульмонологічний журнал. 2013. № 3. С. 7-12. DOI 10.15587/25194798.2019.171024.

${ }^{2}$ Bailey C.J. Metformin: effects on micro and macrovascular complications in type 2 diabetes mellitus // Cardiovascular Drugs and Therapy. 2008. Vol. 22, № 3. P. 215-224. DOI 10.1007/s10557-008-6092-0.

3 Міжнародна класифікація хвороб. URL: https://www.umj.com.ua/article/ 126550/mizhnarodna-klasifikatsiya-hvorob-11-shho-novogo (дата звернення: 23.02.2020). 
Закінчення таблиці 2

\begin{tabular}{|l|l|c|}
\hline \multicolumn{1}{|c|}{ Захворювання } & \multicolumn{1}{|c|}{ Симптоми } & \multicolumn{1}{|c|}{$\begin{array}{c}\text { Група } \\
\text { препаратів для } \\
\text { лікування }\end{array}$} \\
\hline Гострий тонзиліт & $\begin{array}{l}\text { Головний біль, підвищення } \\
\text { температури тіла, ломота в } \\
\text { суглобах, озноб, біль у горлі - } \\
\text { спочатку при ковтанні, а згодом } \\
\text { постійний, збільшення } \\
\text { регіонарних (підщелепних) } \\
\text { лімфовузлів, іх болючість. } \\
\text { Обличчя гіперемійоване, нерідко } \\
\text { спостерігається герпес }\end{array}$ & R02 \\
\hline $\begin{array}{l}\text { Гострий ларингіт } \\
\text { і трахеїт }\end{array}$ & $\begin{array}{l}\text { Помірний біль у горлі та кашель, } \\
\text { гіперемія та набряк слизової } \\
\text { оболонки гортані, потовщення } \\
\text { та гіперемія голосових зв'язок }\end{array}$ & R02, R03 та R05 \\
\hline $\begin{array}{l}\text { Гострий } \\
\text { обструктивний } \\
\text { ларингіт (круп) } \\
\text { та епіглотит }\end{array}$ & $\begin{array}{l}\text { Порушення прохідності } \\
\text { дихальних шляхів на рівні } \\
\text { гортані, спазм м'язів, } \\
\text { гіперсекреція мокротиння, поява } \\
\text { грубого кашлю та зміна голосу } \\
\text { (охриплість), задишка }\end{array}$ & R02, R03 та R05 \\
\hline $\begin{array}{l}\text { Гострі респі- } \\
\text { раторні інфекції } \\
\text { верхніх дихальних } \\
\text { шляхів множиннӧ̈ } \\
\text { та неуточненої } \\
\text { локалізацій }\end{array}$ & $\begin{array}{l}\text { Кашель, сильний біль у горлі, } \\
\text { закладеність носа та } \\
\text { ускладнення дихання, } \\
\text { підвищення температури тіла та } \\
\text { набряк слизової носа та горла }\end{array}$ & R01, R03 та R05 \\
\hline
\end{tabular}

Так, більшість захворювань (фарингіт, ларингіт, тонзиліт, трахеїт) супроводжуються болем у горлі та кашлем. Для їх лікування використовуються препарати групи R02 та R05. Аналізу цих двох груп препаратів автори і присвятять це дослідження.

Кашель як один із симптомів багатьох захворювань дихальної системи $€$ реакцією організму, яка_ (забрати нижнє підкреслення), допомагає очистити дихальні шляхи від слизу та захистити легені. Для лікування кашлю та інших симптомів застуди доступні як безрецептурні препарати, так і ліки, що відпускаються за рецептом. Група препаратів 3 кодом R05 (лікарські засоби, що використовуються при лікуванні кашлю та застудних захворювань) - це одна 3 наймасштабніших груп препаратів, які використовуються при лікуванні кашлю за класифікацією ATC (Anatomical Therapeutic Chemical 
Classification System). Ця група в свою чергу поділяється на підгрупи, які наведено у таблиці $3^{4}$.

Таблиця 3

\section{Класифікація препаратів групи R05}

\begin{tabular}{ll|}
\hline & $\begin{array}{l}\text { R05С-відхаркувальні засоби за виключенням } \\
\text { комбінованих препаратів, які містять } \\
\text { протикашльові засоби. Чинять відхаркувальну, } \\
\text { муколітичну та спазмолітичну дії, знижують } \\
\text { в'язкість мокротиння та сприяють його } \\
\text { відходженню }\end{array}$ \\
\hline
\end{tabular}

R05D - протикашльові засоби за виключенням
комбінованих препаратів, які містять
експекторанти. Зумовлюють протикашльову,
жарознижувальну, знеболювальну та
деконгестивну дії

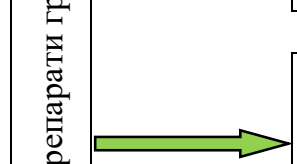

$\mathrm{R} 05 \mathrm{~F}$ - комбіновані препарати, які містять протикашльові засоби та експекторанти.

Впливають на центральну ланку кашльового рефлексу, внаслідок чого зменшується сухий непродуктивний кашель

$\mathrm{R} 05 \mathrm{X}$ - інші комбіновані препарати, які застосовуються при кашлі та застудних захворюваннях. Ці засоби активують секреторну функцію епітелію, змінюють властивості легеневого сурфактанту, стимулюють функцію ворсинок епітелію

4 Фітьо І.В., Стадницька Н.С., Малтиз І.С., Милянич А.О., Комар А.В., Новіков В.П. Статистичний аналіз лікарських препаратів для лікування кашлю та застудних захворювань, які представлені на ринку України : Матеріали міжнар. наук.практ. конф. [“Planta+. Досягнення та перспективи”], (Київ, 20-21 лют 2020 р.) / Національний медичний університет ім. О.О. Богомольця. 2020. С. 186-188.

Конопкіна Л.І. Рівень маркерів системного запалення у хворих на хронічне обструктивне захворювання легень тяжкого перебігу залежно від прихильності їх до планової терапії // Проблеми екології та медицини. Дніпропетровськ, 2012. Т. 16, № 5-6. C. 15-18. 
Загальна кількість препаратів із кодом АTC R05 станом на лютий 2020 року на фармацевтичному ринку України складала 450 одиниць ${ }^{5}$. На рис. 1 наведено результати проведеного аналізу препаратів за лікарською формою. Більшість із них представлена у вигляді сиропів (близько 36\%), найменша частка належить розчинам для інгаляцій, мікстурам та емульсіям - менше $2 \%{ }^{6}$.

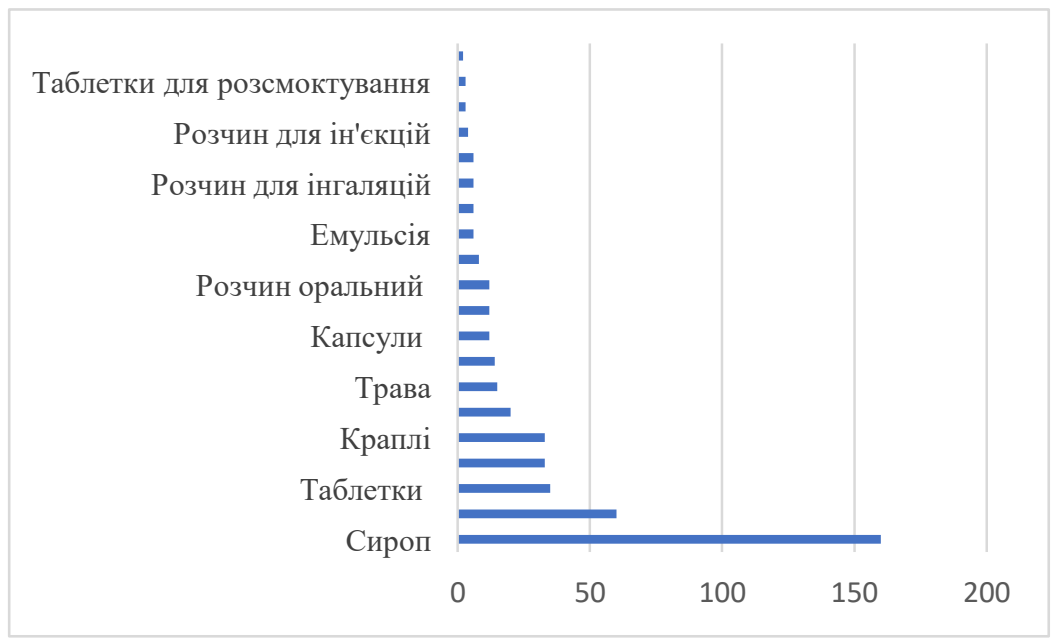

\section{Рис. 1. Розподіл лікарських засобів групи R05 за лікарською формою}

Більше половини препаратів групи R05 складають препарати синтетичної природи (62\%), рослинним препаратам належить частка $34 \%$, комбіновані препарати складають 4\%. Серед них найбільше препаратів містять в якості діючої речовини ацетилцистеїн $(23,5 \%)$ та бромгекседину гідрохлорид $(14,4 \%)$. Широке використання цих речовин зумовлене їх фармакологічною дією, яка полягає у розрідженні мокротиння та пригніченні кашлевого рефлексу.

Рослинні засоби використовуються у вигляді однокомпонентних препаратів 36\% або багатокомпонентних 64\% (рис. 2).

\footnotetext{
${ }^{5}$ Спеціалізоване медичне інтернет-видання для лікарів, провізорів, фармацевтів, студентів медичних i фармацевтичних вузів “Компендіум". URL: https://compendium.com.ua (дата звернення: 29.02.2020).

6 Державний реєстр лікарських засобів України. URL: http://www.drlz.com.ua (дата звернення: 29.02.2020).
} 


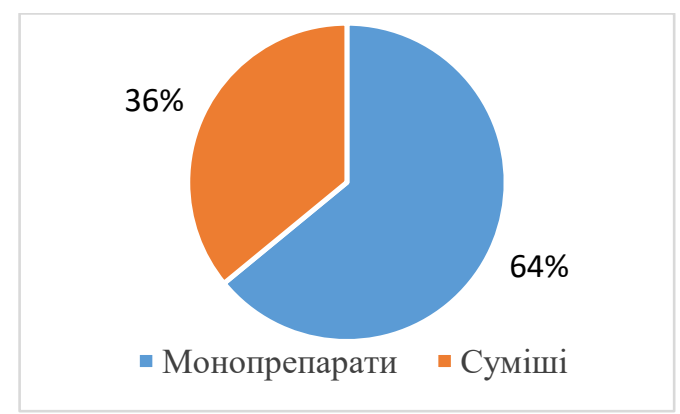

\section{Рис. 2. Розподіл рослинних препаратів на одно- та багатокомпонентні}

Наступним симптомом, який супроводжує захворювання дихальних шляхів, $\epsilon$ біль у горлі. Препарати, що використовуються при захворюванні горла, мають кодування R02 і поділяються на групи:

- R02A A - Антисептики.

- R02А B - Антибіотики.

- R02AD - Місцеві анестетики.

- R02A X - Інші засоби, які застосовуються при захворюваннях горла.

Як бачимо із назв груп препаратів, їх дія спрямована на знищення паталогічної мікрофлори та забезпечення знеболюючого ефекту. Інформацію стосовно форми препаратів із кодом АTC R02, кількість яких станом на лютий 2020 року становить 183 найменування, наведено на рисунку 3. Більшість із них представлена у вигляді спреїв та аерозолів (26\%), найменша частка належить порошкам, сумішам i зборам (близько 1\%).

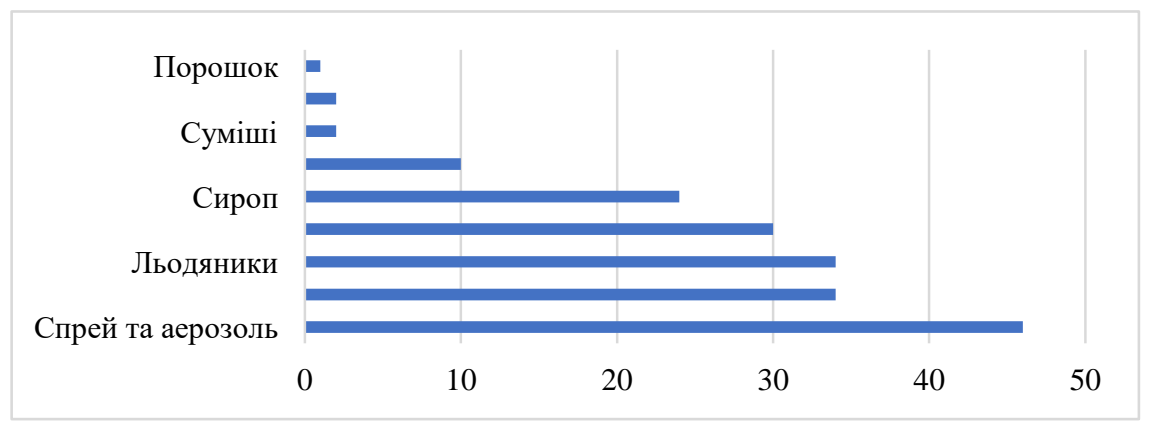

Рис. 3. Розподіл лікарських засобів групи R02 за лікарською формою 
Оскільки для лікування захворювань горла значну частку сегменту ринку займають препарати у формі спрею, в той час як при лікуванні кашлю ця форма практично відсутня, автори вирішили переглянути всі переваги цієї лікарської форми.

\section{2. Обгрунтування застосування лікарської форми "спрей" для лікування захворювань дихальних шляхів}

Фармацевтичні спреї для зовнішнього застосування займають найважливіше місце серед аерозольних лікарських форм i широко використовуються в дерматології, хірургії, гінекології, акушерстві і проктології. Теоретично і практично всі захворювання місцевого характеру можна лікувати аерозольними препаратами ${ }^{7}$.

Аерозоль або ж спрей як лікарська форма має багато переваг, основна $з$ яких полягає у високій дисперсності і легкій рухливості часток дисперсної фази - факторів, які підвищують фармакологічну активність ліків. При застосуванні спрею ліки не зазнають тих змін, які мають місце при прийомі перорально, тобто відсутні фактори впливу на ліки шлункового і кишкового соку, бар'єру печінки, не відбуваються їх втрати.

Аерозолі $€$ аеродисперсними системами із газоподібним дисперсійним середовищем і вільними твердими чи рідкими частками дисперсної фази. У медичній практиці знаходять застосування не тільки високодисперсні аерозолі (0,1-0,5 мкм), але і низько (25-100 мкм) і грубо-дисперсні (250-400 мкм). Цей термін іноді неправильно використовується для позначення спеціального виду упакування, в якому знаходиться стиснутий або зріджений газ, що використовується для виштовхування (витиснення, евакуації) продукту, що міститься в ньому ${ }^{8} .3$ фармацевтичної точки зору “аерозоль” $\epsilon$ формою випуску готового лікарського засобу, коли одна чи кілька лікарських речовин у розчиненому, суспендованому чи емульгованому стані міститься у газі, у спеціальному балоні, закритому клапанорозпилюючим пристроєм.

У виробництві спреїв та аерозолів досі використовуються шкідливі пропеленти, проте 3 кожним роком виробники лікарських засобів

${ }^{7}$ Iryna Diakon, Nataliya Stadnytska, Volodymyr Novikov. Alternative Methods for Replacing Propellants in the Medical Form "Spray" : Proceedings of the 2nd International Scientific Conference ["Chemical Technology and Engineering"], (Lviv, June 24-28, 2019) / Lviv Polytechnic National University, 2019. P. 392-393. DOI 10.23939/cte2019.01.392.

8 Dyakon I. Propellants in the spray production. LAP LAMBERT Academic Publishing. Riga, 2018. 52 p. 
переходять на альтернативні способи пакування. Йдеться про заміну озоноруйнуючих речовин $\mathrm{y}$ аерозолях механічними клапаннорозпорошувальними системами: механічними насосами, стисненими балонами та бар'єрними перегородками. Перевагами таких упаковок $\epsilon$ повна вибухобезпека, багаторазовість використання, можливість більш ефективного використання внутрішнього об'єму балона.

Видача вмісту балона при використанні механічного насоса відбувається стисненим повітрям. За допомогою мікронасосу створюється тиск повітря в балоні до 5 атм., що забезпечує виштовхування точної дози однорідних ліків. Цей тип упаковки можна вважати актуальним для будь-якого продукту. Крім механічних насосів, використовують стиснені балони, які виготовляють із еластичних полімерів. Принцип їх роботи базується на дії м'язевої сили стиску і видавлювання продукту через сопло з малим перерізом. Такі упаковки є найдешевшими, оскільки не потребують затрат на складні комплектуючі. Перерахованим упаковкам притаманна одна загальна вада - неможливість досягнення достатнього внутрішнього тиску порівняно з тиском, який створюється у контейнерах зі зрідженими пропелентами.

Зважаючи на недоліки та переваги розглянутих видів упакувань, розроблені конкурентно здатні контейнери для спреїв. Для прикладу, технологія клапан-пакетів (Bag On Valve), розроблена компанією Aptar Pharma, визнана дуже зручною та економічною. Ця технологія забезпечує безперервне розпорошення i функціональність при обертанні на 360 градусів, а також забезпечує краще збереження i захист вмісту.

Технологія Bag On Valve (рис. 4) також відкриває нові можливості в упаковці фармацевтичних продуктів на водній основі, оскільки вона відповідає новим регуляторним нормам щодо безперервного розпилення препарату. Основні переваги цієї системи:

- безперервне розпилення;

- забезпечення високого захисту продукту протягом усього терміну придатності;

- розпилення в усіх напрямках (на 360 градусів);

- повне розділення продукту і газу (пропелент або ж звичайне повітря не вступає у контакт із препаратом у пакеті);

- вивільнення до 99,7\% вмісту балона. 

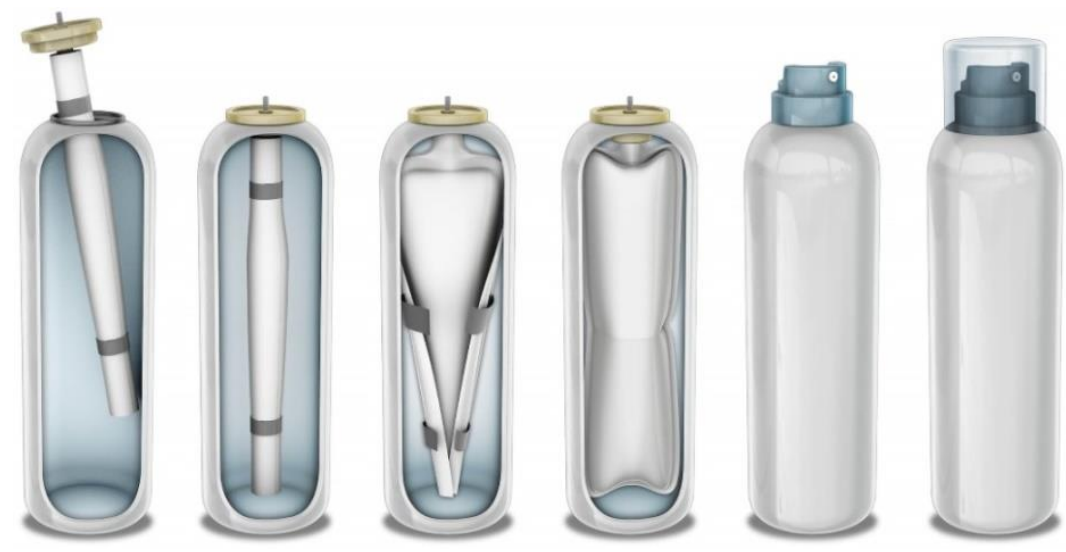

\section{Рис. 4. Упакування Bag On Valve}

Отже, сучасні технології пакувальних контейнерів дозволяють розробляти ефективні, екологічно безпечні, зручні у використанні спреї для медичних цілей.

\section{3. Розробка нового лікарського засобу для лікування захворювань дихальної системи комплексної дії}

Провівши аналіз асортименту груп препаратів R02 та R05, представлених на фармацевтичному ринку України, можна зробити висновок, що доцільно розробити новий лікарський засіб для лікування захворювань дихальної системи, який би містив у своєму складі компоненти 3 антимікробною та муколітичною діями. Це дозволить усувати кашель і біль у горлі при застосуванні одного засобу, що дуже зручно хворому. Враховуючи представлені вище результати аналізу форм лікарських засобів, які використовуються для лікування захворювань горла, а також при кашлі та застудних захворюваннях, обрано форму спрею для розробки складу препарату для лікування захворювань дихальної системи комплексної дії.

Оскільки лікарські засоби із вмістом рослинних субстанцій $\epsilon$ популярними серед населення України у зв'язку із їх ефективністю та безпечністю, увагу було спрямовано на вибір рослинних компонентів для нового препарату. Згідно 3 попередніми дослідженнями ${ }^{9}$,

9 Белей С.Я., Грошовий Т.А., Белей Н.М., Дарзулі Н.П. Дослідження асортименту відхаркувальних фітопрепаратів для лікування кашлю при застудних 
17\% фітозасобів для лікування кашлю, представлених на фармацевтичному ринку нашої країни, містять витяжки листя плюща, на другому місці знаходяться препарати із вмістом коріння алтеї (12\%), відсоток препаратів із вмістом іншої лікарської рослинної сировини, такої як сосни бруньки, листя подорожника, трава чебрецю, листя підбілу, плоди анісу, трава багна, корінь солодки та оману, трава материнки та фіалки, слань моху ісландського, є незначним - 6\% i менше. Серед офіційних лікарських рослин вираженою антимікробною активністю володіє представник родини Миртові Myrtaceae евкаліпт кулястий Eucalyptus globulus, а представник родини пармелієві Parmeliaceae мох ісландський Cetraria islandica $\epsilon$ джерелом полісахаридів із муколітичною дією. Саме тому ці рослини було вибрано для розробки нового фітозасобу згаданої дії.

Cetraria islandica належить до листоподібних кущових лишайників. В Україні зростає практично по всій території у соснових лісах на болотах і високогір'ї. Лікарською рослинною сировиною $є$ слань (Lichen islandicus), яка нагадує кущоподібне, прямостояче, неправильно розгалужене утворення. Частки талома стрічкоподібної форми, шкірясто-хрящуваті, плоскі, облямовані по краю короткими волосками, зверху зеленувато-бурого або маслиново-зеленого, знизу сіруватобілуватого кольору, при основі досить часто видно червоні плямки, на верхівках сильно розгалужених частках знаходяться плодові тіла плоскі, круглі, дископодібні апотеції. Сировина має слабкий своєрідний запах і гірко-слизистий смак ${ }^{10}$.

Слань лишайника містить до $80 \%$ вуглеводів (первинний ліхенін, лінійний целюлозоподібний полімер $\beta$-глюкози та ізоліхенін D-полімер глюкози), 3\% - білків, 2\% - жирів, близько 3\% пігментів і 3-5\% лишайникових кислот (уснинова, ліхестеринова, фумарпротоцентарова), вітаміни $\mathrm{A}, \mathrm{C}, \mathrm{B}_{1}, \mathrm{~B}_{12}$, солі хрому, цинку, марганцю, титану, бору, міді, молібдену, заліза та йоду ${ }^{11}$.

захворюваннях // Фармацевтичний часопис. 2018. № 2. C. 82-87. DOI 10.11603/23120967.2018.2.9126.

10 Ingolfsdottir K., Hjalmarsdottir M., Sigurdsson A., Gudjonsdottir G., Brynjolfsdottir A., Steingrimsson O. In vitro susceptibility of Helicobacter pylori to protolichesterinic acid from the lichen Cetraria islandica // Antimicrobial Agents Chemotherapy. 1997. 41 (1). P. 215-217.

${ }^{11}$ Katalinic V., Milos M., Kulisic T., Jukic M. Screening of 70 medicinal plant extracts for antioxidant capacity and total phenols // Food Chemistry London: Elsevier. 2006. № 94. P. 550-557. DOI 10.1016/j.foodchem.2004.12.004. 


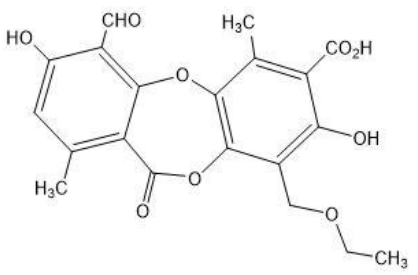

Цетрарова кислота

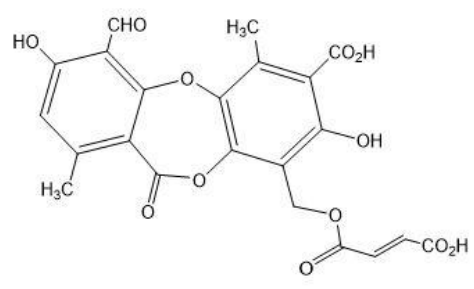

Протоцетрарова кислота

Мох ісландський широко застосовують у народній медицині для відновлення сил, у лікуванні хвороб шлунково-кишкового тракту (різних видів гастритів, виразкової хвороби), дистрофії, загального виснаження організму; Cetraria islandica входить до складу комплексних оздоровчих програм лікування i профілактики захворювань дихальних шляхів і легень (гострий і хронічний бронхіт, кашель різної етіології, застійні явища при хронічних гайморитах, синуситах, бронхіальній астмі, туберкульозі), інфекційних захворювань дихальних шляхів (коклюш), інфекційних захворювань шкіри, опіків, вугрів і дерматитів (у тому числі і алергічного генезу), первинних $\mathrm{i}$ вторинних порушень діяльності щитоподібної залози у вигляді дисфункцій ендокринної системи, баріатричних змін, альгодисменореї, профілактики кістозних змін у гінекології. Лишайникові кислоти, зокрема уснинова, згубно діють на стафілококи, стрептококи та мікобактерії туберкульозу ${ }^{12}$.

Лікувальний ефект препаратів моху ісландського полягає в муколітичній дії, антимікробній активності та імуностимулюючих властивостях його екстрактів, що доведено результатами наукових досліджень. Оскільки мох ісландський має ще й захисні властивості, його можна застосовувати з метою профілактики інфекційно-запальних захворювань ротової порожнини та глотки. Коли існує небезпека застуди, профілактичне застосування препарату моху ісландського, здатного захищати слизові оболонки, значно знижує схильність дихальних шляхів до різного роду інфекцій. Полісахариди, які містяться в препараті, обволікають слизові оболонки повітроносних шляхів і ефективно захищають їх від дії шкідливих зовнішніх факторів і різного виду подразників.

12 EMA/HMPC/36866/2014 Committee on Herbal Medicinal Products. URL: https://www.ema.europa.eu/en/documents/herbal-report/draft-assessment-report-cetrariaislandica-l-acharius-sl-thallus_en.pdf (дата звернення: 10.03.2020). 
Перевірені інгібуючі ефекти полісахариду, виділеного з Cetraria islandica, складається 3 D-глюкопіранозильних одиниць. При концентрації 100 мг/мл полісахариди знижують комплементарноіндукований гемоліз приблизно на 80\%. Різні витяжки із Cetraria islandica мають певні застереження при застосуванні. Використання водних екстрактів зі співвідношенням сировина-готовий екстракт дорівнює 2-4:1 (не рекомендується вживати дітям до 6 років).

Наступною рослинною сировиною, пропонованою для складу нового засобу, є евкаліпт кулястий Eucalyptus globulus. Це вічнозелене дерево до 45-55 (70) м заввишки 3 добре розгалуженою кореневою системою. Для молодих рослин Eucalyptus globulus характерні широкі листкові пластинки довжиною близько 6-15 см, покриті сіроблакитним, восковим нальотом. Перші листки молодих пагонів протилежні, сидячі, овально-довгасті, 3 серцеподібною основою, мучнисто-блакитні; старші листки звисають, спірально розташовані, ланцетно-серповидні. Листки дорослих рослин вузькі, серпоподібні, блискучі й темно-зелені $15-35$ см завдовжки від світло-зеленого до сіро-зеленого іноді із фіолетовим відтінком і слабким сизим нальотом, голі з цільним, рівним або хвилястим краєм із численними залозками 3 умістом ефірних олій, які просвічуються на світлі ${ }^{13}$.

Витяжки 3 листя евкаліпту діють на стафілококи, стрептококи, паличку черевного тифу і паратифи А і Б, паличку дезинтерії, кишкову паличку, гнійних та анаеробних збудників. Евкаліпт має антибактеріальну, протигрибкову, противірусну, в'яжучу, кровоспинну, протизапальну та знеболювальну, антиоксидантну, антидіабетичну, репелентну дії.

Евкаліптові препарати використовують для лікування фурункулів та інших гнійних інфекцій (нариви, флегмони, остеомієліти), виразок, гнійних і свіжих ран і відкритих переломів; у разі гострих кишкових інфекцій та диспепсичних розладів (блювота, пронос, різі і тому подібне), катарів верхніх дихальних шляхів (застуда, бронхіт, кашель), інфекцій горла, лікування стоматитів і гінгівітів ${ }^{14}$. Народна медицина застосовує евкаліпт як антигельмінтний засіб, а також для лікування

${ }^{13}$ Ellagic acid rhamnosides from the stem bark of Eucalyptus globulus / Kim JongPyung, Lee In-Kyoung, Yun Bong-Sik et al. // Phytochemistry: The International Journal of Plant Biochemisery. 2001. Vol. 57, № 4. P. 587-591. DOI 10.1016/S00319422(01)00146-7.

${ }^{14}$ Eucalyptone from Eucalyptus globulus / Osowa Kenji, Yasuda Hideyuki, Marita Hiroshi et al. // Phytochemistry: The International Journal of Plant Biochemisery. 1995. Vol. 40, № 1. P. 183-184. DOI 10.1016/0031-9422(95)00233-w. 
дифтерії, скарлатини, малярії. Слід звернути увагу, що евкаліпт протипоказаний при вагітності та підвищеному артеріальному тиску.

У листі Eucalyptus globulus є смоли, віск, органічні кислоти, дубильні речовини, ефірна олія, фенольні сполуки, хлорофіл. Багато робіт присвячено вивченню компонентів ефірних олій ${ }^{15}$. В ефірній олії Eucalyptus globulus виявлено 72 сполуки. Терпенові сполуки представлено циклічними, ациклічними та ароматичними монотерпеноїдами і сесквітерпеноїдами.

Початок розробки будь-якого нового продукту потребує проведення аналізу патентної чистоти для обраного складу з метою забезпечення збереження усіх прав на продукт. Лікарський засіб, де діючими речовинами $\epsilon$ водний екстракт моху ісландського та спиртовий екстракт евкаліпту кулястого, не буде порушувати права власників патентів, діючих на території України, адже на національному фармацевтичному ринку відсутні препарати із обраною композицією екстракт моху - екстракт евкаліпту.

Отож для розробки нового лікарського засобу використано два рослинні екстракти: густий водний екстракт моху ісландського із таким співвідношенням сировини: екстракт 1:10 і густий спиртовий екстракт евкаліпту кулястого із співвідношенням сировини: екстракт 1:15,3. Препарат порівняння відсутній, оскільки обрано для розробки продукт оригінального складу.

При виборі допоміжних речовин автор враховував фармакотехнологічні характеристики, якими повинен володіти продукт у лікарській формі спрею оромукозного, дозування продукту, розмір частинок тощо. Оскільки субстанція евкаліпту - екстракт густий - $\epsilon$ не розчинною у воді, було вирішено використовувати допоміжні речовини таких функціональних груп:

- розчинник,

- структуроутворювач,

- підсолоджувач.

Терапевтичний ефект спрею залежить від хімічних, структурномеханічних властивостей складників, діючих і допоміжних речовин, їх концентрації, агрегатного та дисперсного стану. Саме допоміжні речовини мають забезпечувати потрібну концентрацію лікарської форми, легко вивільняти та бути сумісними із діючими речовинами спрею. Крім того, допоміжні речовини допомагають забезпечити якість

${ }^{15}$ Viralkumar F., Fang L., Marc B. Advances in oral transmucosal drug delivery // Journal of Controlled Release London: Elsevier. 2011. Volume 153. P. 84-85. DOI 10.1016/j.jconrel.2011.01.027. 
продукту, створити його структуру та підтримувати терапевтичний ефект діючих речовин ${ }^{16}$.

Для цього продукту використано таку систему розчинників: гліцерин: етанол: вода очищена. Таке поєднання дозволяє виготовити продукт, вигідний із економічної точки зору. Завдяки не специфічним органолептичним властивостям склад продукту не вимагає введення ароматизатору.

Склад готового продукту, підібраний у ході експерименту, наведено у табл. 4.

Таблиця 4

\section{Склад препарату}

\begin{tabular}{|l|l|c|}
\hline \multicolumn{1}{|c|}{$\begin{array}{c}\text { Найменування } \\
\text { компонентів }\end{array}$} & \multicolumn{1}{|c|}{ Функціональне призначення } & Кількість \\
\hline $\begin{array}{l}\text { Екстракт моху } \\
\text { ісландського }\end{array}$ & $\begin{array}{l}\text { Активний фармацевтичний } \\
\text { інгредієнт. Чинить } \\
\text { відхаркувальну та } \\
\text { пом’якшувальну дію }\end{array}$ & 6,00 г \\
\hline $\begin{array}{l}\text { Екстракт евкаліпту } \\
\text { кулястого }\end{array}$ & $\begin{array}{l}\text { Активний фармацевтичний } \\
\text { інгредієнт. Виявляє } \\
\text { бактеріостатичний ефект на } \\
\text { слизову оболонку горла }\end{array}$ & 0,26 г \\
\hline $\begin{array}{l}\text { Етанол: вода } \\
\text { очищена }\end{array}$ & Система розчинників & $14,00: 14,00$ мл \\
\hline Гліцерин & $\begin{array}{l}\text { Структуроутворювач, також } \\
\text { входить до системи } \\
\text { розчинників }\end{array}$ & До 100,00 мл \\
\hline
\end{tabular}

Для приготування лікарського засобу у лабораторних умовах 0,26 г густого екстракту евкаліпту кулястого розчиняли у 14 мл етанолу 96\%, ретельно перемішували. В іншій колбі розчиняли 6 г густого екстракту моху ісландського у 14 мл води очищеної. Обидва отримані екстракти об'єднували та доводили до 100 мл гліцерином.

Кінцевою метою будь-якого продукту 3 точки зору якості $\epsilon$ відповідність специфікації. Адже контроль якості - це частина належної виробничої практики, пов'язана із проведенням випробувань, які гарантують, що дійсно проведені всі необхідні й відповідні випробування і що матеріали не будуть дозволені для використання до того часу, поки їх якість не буде визнана задовільною.

${ }^{16}$ Морозова С.В. Розробка складу і технології спрею на основі фіто композиції протигрибкової дії : Дисертація на здобуття кандидата фармацевтичних наук / Морозова Єлизавета Володимирівна. П'ятигорськ, 2009. С. 168. 
У табл. 5 наведено встановлені попередні вимоги до якості готового спрею оромукозного, розробленого в лабораторних умовах на основі моху ісландського та евкаліпту кулястого.

Таблиця 5

Вимоги до якості запропонованого продукту

\begin{tabular}{|c|c|c|}
\hline $\begin{array}{c}\text { Найменування } \\
\text { показника }\end{array}$ & Вимоги & Фактичні результати \\
\hline Опис & $\begin{array}{l}\text { Рідина темно-коричневого } \\
\text { кольору. Не допускається } \\
\text { утворення осаду }\end{array}$ & $\begin{array}{l}\text { Не відповідає вимогам. } \\
\text { Спостерігається } \\
\text { утворення коричневого } \\
\text { осаду на дні балону }\end{array}$ \\
\hline $\begin{array}{l}\text { Ідентифікація } \\
\text { Хлорофіли }\end{array}$ & $\begin{array}{l}\text { Ультрафіолетовий спектр } \\
\text { поглинання отриманого } \\
\text { розчину в області від } 600 \text { нм } \\
\text { до } 700 \text { нм повинен мати } \\
\text { максимум за довжини хвилі } \\
(652 \pm 2) \text { нм }\end{array}$ & Відповідає \\
\hline $\begin{array}{l}\text { Обсяг вмісту } \\
\text { упаковки }\end{array}$ & Не менше 100.0 мл & Відповідає \\
\hline $\begin{array}{l}\text { Мікробіологічна } \\
\text { чистота }\end{array}$ & $\begin{array}{l}\text { Загальна кількість } \\
\text { життєздатних аеробних } \\
\text { мікроорганізмів - не більше } \\
10 \text { мікроорганізмів (бактерій } \\
\text { і грибів сумарно) на 1 мл } \\
\text { лікарського засобу. } \\
\text { Відсутність ентеробактерій і } \\
\text { деяких інших } \\
\text { грамнегативних бактерій в } 1 \\
\text { мл лікарського засобу. } \\
\text { Відсутність Pseudomonas } \\
\text { aeruginosa в } 1 \text { мл лікарського } \\
\text { засобу. } \\
\text { Відсутність Staphylococсus } \\
\text { aureus в } 1 \text { мл лікарського } \\
\text { засобу }\end{array}$ & Відповідає \\
\hline Вміст етанолу & Не більше $14 \%$ & Відповідає \\
\hline $\begin{array}{l}\text { Антибактеріальна } \\
\text { активність }\end{array}$ & $\begin{array}{l}\text { Лікарський засіб має } \\
\text { пригнічувати ріст тест- } \\
\text { культури Staphylococcus } \\
\text { aureus ATCC 6538-P y } \\
\text { концентрації не більше 12,5 } \\
\text { мкг в 1 мл середовища } \\
\end{array}$ & Відповідає \\
\hline $\begin{array}{l}\text { Кількісне } \\
\text { визначення }\end{array}$ & $\begin{array}{l}\text { Вміст поліцукрів у } \\
\text { перерахунку на суху } \\
\text { речовину має становити не } \\
\text { менше } 40 \%\end{array}$ & $\begin{array}{l}\text { Не відповідає. } \\
\text { Вміст поліцукрів } \geq 36 \%\end{array}$ \\
\hline
\end{tabular}


Готовий продукт спрей оромукозний на основі екстракту моху ісландського та евкаліпту кулясного - опалесцентна рідина від зеленокоричнуватого до коричневого кольору зі специфічним запахом по 100 мл у флаконі темного скла, укомплектованого з'ємною насадкоюрозпилювачем і захисним ковпачком для флакону.

Велику увагу приділено дослідженню антибактеріальної активності продукту. Антибактеріальну активність визначали мікробіологічним методом із використанням 2-х кратних серійних розведень у соєвоказеїновому бульйоні із тест-мікроорганізмом Staphylococcus aureus (25000 мікробних клітин у 1 мл). Для випробування брали 3 ряди пробірок по 4 в кожному. Облік результатів випробування проводили після інкубації за температури $(32,5 \pm 2,5)^{\circ} \mathrm{C}$ протягом 48 год. Антибактеріальну активність досліджуваного зразка оцінювали візуально. Результати наведено у табл. 6.

Таблиця 6

Антибактеріальна активність досліджуваного спрею

\begin{tabular}{|l|c|c|c|c|}
\hline \multirow{2}{*}{\multicolumn{1}{|c|}{ Досліджуваний зразок }} & \multicolumn{4}{|c|}{ Концентрація, мкг/мл } \\
\cline { 2 - 5 } & $\mathbf{5 0}$ & $\mathbf{2 5}$ & $\mathbf{1 2 , 5}$ & $\mathbf{6 , 2 5}$ \\
\hline Екстракт Evcaliptus globulus & - & - & - & + \\
\hline $\begin{array}{l}\text { Досліджуваний спрей із } \\
\begin{array}{l}\text { Evcaliptus globulus } \text { i Cetraria } \\
\text { islandica }\end{array}\end{array}$ & + & + & + & + \\
\hline \multicolumn{7}{|l|}{ - активність присутня; - - активність відсутня } \\
\hline
\end{tabular}

Так, поєднання екстракту евкаліпту та екстракту моху ісландського підсилює антибактеріальну дію самого евкаліпту. Це дає змогу зробити висновки про сумісність і комплексну дію цих двох екстрактів при створенні продукту для лікування захворювань дихальних шляхів.

\section{ВИСНОВКИ}

Запропоновано склад нового оромукозного спрею на основі екстрактів моху ісландського Cetraria islandica та евкаліпту кулястого Eucalyptus globulus, який, на жаль, не витримав вимог специфікації якості стосовно стабільності. Після зберігання протягом 6 місяців утворювався осад коричневого кольору, що свідчить про осадження деяких біологічно активних речовин. У зв'язку з цим необхідно продовжити дослідження та вводити до складу продукту емульгатор, який забезпечить стабільність. 


\section{АНОТАЦІЯ}

Одним із основних завдань фармацевтичної технології $\epsilon$ вдосконалення існуючих, створення i впровадження в медичну практику нових лікарських засобів із максимальним терапевтичним ефектом і мінімальною побічною дією.

Фармацевтична розробка передбачає створення оптимальної лікарської форми та технології iï отримання. Досягти цих вимог можна тільки за рахунок проведення великої кількості досліджень, які дозволять здійснити науково-обгрунтоване вивчення якісних $\mathrm{i}$ кількісних факторів.

У процесі створення лікарської форми виникла необхідність у проведенні ретельного вибору серед значної кількості тих або інших груп активних інгредієнтів та допоміжних речовин.

У цій роботі представлено результати зі створення нового препарату на основі двох різних за фізико-хімічними характеристиками рослинних екстрактів - моху ісландського Cetraria islandica та евкаліпту кулястого Eucalyptus globulus. Лікарською формою готового засобу було обрано спрей оромукозний як найбільш практичну форму, яка чинить місцеву дію при інфекційних захворюваннях дихальних шляхів.

Проаналізовано відповідність створеного продукту специфікації якості. По антимікробних показниках запропонований склад спрею виявився придатним, однак не витримав перевірку на стабільність i потребує подальшого доопрацювання.

\section{ЛІТЕРАТУРА}

1. Фещенко Ю.І., Яшина Л.О., Дзюблик О.Я. Хронічне обструктивне захворювання легень: етіологія, патогенез, класифікація, діагностика, терапія // Український пульмонологічний журнал. 2013. № 3. C. 7-12. DOI 10.15587/2519-4798.2019.171024.

2. Bailey C.J. Metformin: effects on micro and macrovascular complications in type 2 diabetes mellitus // Cardiovascular Drugs and Therapy. 2008. Vol. 22, № 3. P. 215-224. DOI 10.1007/s10557-008-6092-0.

3. Міжнародна класифікація хвороб. URL: https://www.umj.com.ua /article/126550/mizhnarodna-klasifikatsiya-hvorob-11-shho-novogo (дата звернення: 23.02.2020).

4. Фітьо І.В., Стадницька Н.С., Малтиз І.С., Милянич А.О., Комар А.В., Новіков В.П. Статистичний аналіз лікарських препаратів для лікування кашлю та застудних захворювань, які представлені на ринку України : Матеріали міжнар. наук.-практ. конф. [“Planta+. 
Досягнення та перспективи"], (Київ, 20-21 лют 2020 р.) / Національний медичний університет ім. О.О. Богомольця. 2020. С. 186-188.

5. Конопкіна Л.І. Рівень маркерів системного запалення у хворих на хронічне обструктивне захворювання легень тяжкого перебігу залежно від прихильності їх до планової терапії // Проблеми екології та медицини. Дніпропетровськ, 2012. Т. 16, № 5-6. С. 15-18.

6. Спеціалізоване медичне інтернет-видання для лікарів, провізорів, фармацевтів, студентів медичних і фармацевтичних вузів "Компендіум". URL: https://compendium.com.ua_(дата звернення: 29.02.2020).

7. Державний реєстр лікарських засобів України. URL: http://www.drlz.com.ua (дата звернення: 29.02.2020).

8. Iryna Diakon, Nataliya Stadnytska, Volodymyr Novikov. Alternative Methods for Replacing Propellants in the Medical Form "Spray" : Proceedings of the 2nd International Scientific Conference ["Chemical Technology and Engineering"], (Lviv, June 24-28, 2019) / Lviv Polytechnic National University, 2019. P. 392-393. DOI 10.23939/cte2019.01.392.

9. Dyakon I. Propellants in the spray production. LAP LAMBERT Academic Publishing. Riga, 2018. 52 p.

10. Белей С.Я., Грошовий Т.А., Белей Н.М., Дарзулі Н.П. Дослідження асортименту відхаркувальних фітопрепаратів для лікування кашлю при застудних захворюваннях // Фармацевтичний часопис. 2018. № 2. С. 82-87. DOI 10.11603/2312-0967.2018.2.9126.

11. Ingolfsdottir K., Hjalmarsdottir M., Sigurdsson A., Gudjonsdottir G., Brynjolfsdottir A., Steingrimsson O. In vitro susceptibility of Helicobacter pylori to protolichesterinic acid from the lichen Cetraria islandica // Antimicrobial Agents Chemotherapy. 1997. 41 (1). P. 215-217.

12. Katalinic V., Milos M., Kulisic T., Jukic M. Screening of 70 medicinal plant extracts for antioxidant capacity and total phenols // Food Chemistry London: Elsevier. 2006. № 94. P. 550-557. DOI 10.1016/j.foodchem.2004.12.004.

13. EMA/HMPC/36866/2014 Committee on Herbal Medicinal Products. URL: https://www.ema.europa.eu/en/documents/herbal-report/draft-assessmentreport-cetraria-islandica-l-acharius-sl-thallus_en.pdf (дата звернення: 10.03.2020).

14. Ellagic acid rhamnosides from the stem bark of Eucalyptus globulus / Kim Jong-Pyung, Lee In-Kyoung, Yun Bong-Sik et al. // Phytochemistry: The International Journal of Plant Biochemisery. 2001. Vol. 57, № 4. P. 587-591. DOI 10.1016/S0031-9422(01)00146-7.

15. Eucalyptone from Eucalyptus globulus / Osowa Kenji, Yasuda Hideyuki, Marita Hiroshi et al. // Phytochemistry: The International Journal 
of Plant Biochemisery. 1995. Vol. 40, № 1. P. 183-184. DOI 10.1016/00319422(95)00233-w.

16. Viralkumar F., Fang L., Marc B. Advances in oral transmucosal drug delivery // Journal of Controlled Release London: Elsevier. 2011. Vol. 153. P. 84-85. DOI 10.1016/j.jconrel.2011.01.027.

17. Морозова Є.В. Розробка складу і технології спрею на основі фітокомпозиції протигрибкової дії : Дисертація на здобуття кандидата фармацевтичних наук / Морозова Слизавета Володимирівна. П’ятигорськ, 2009. с. 168.

Information about authors: Fito I. V., PhD Student of Department of Technology of Biologically Active Substances, Pharmacy and Biotechnology Lviv Polytechnic National University; 12, Bandera str., Lviv, 79013, Ukraine

Stadnytska N. Ye., Candidate of Chemical Sciences, Associate Professor, Associate Professor at the Department of Technology of Biologically Active Substances, Pharmacy and Biotechnology Lviv Polytechnic National University, 12, Bandera str., Lviv, 79013, Ukraine 